\title{
Hybrid ventilation in residential buildings - the proposal of research for the Polish climatic conditions
}

\author{
Maria Kostka ${ }^{1, *}$ \\ ${ }^{1}$ Wrocław University of Science and Technology, Faculty of Environmental Engineering, Wrocław, \\ Poland
}

\begin{abstract}
Due to the geographic location and the influence of the polar maritime and polar continental air masses we observe a large variety and variability of external air parameters in Poland. Both during the whole year and also in shorter, even several-day periods. The parameters of outside air indicate that combination of mechanical and natural ventilation in detached buildings can be cost-effective and allows keeping the thermal comfort and good indoor air quality.
\end{abstract}

\section{Climate}

Poland is located in the transitional area between temperate oceanic climate on the west, a temperate continental on the east. The biggest influence on the climate are polar maritime air masses (ca. $60 \%$ of the days in a year) and polar continental air masses (ca. $30 \%$ of the days in a year). The first of these, causes cloudiness and high relative humidity in summer, while in winter - warming and the appearance of fog. The second of them carry a high temperature in summer and heavy frosts in winter. Moderate weather, warm, cloudy and without precipitation is the most common type. According to A. Woś [1] this type of weather occurs in central Poland for about $25 \%$ of time in summer, and for $17 \%$ of time in spring and autumn. Figure 1 shows the duration of the outside air temperature for Poland and Wrocław, developed on the basis of the statistical climate data from 58 weather stations, provided by the Ministry of Infrastructure and Construction [2]. The analysis does not include three stations (Hel, Śnieżka and Kasprowy Wierch), which, due to their location, are not representative of the whole country. The number of hours with the temperature below $0^{\circ} \mathrm{C}$ in Wrocław is $4 \%$ reduced in comparison with the national average. The total number of hours with the temperature between $0^{\circ} \mathrm{C}$ and $20^{\circ} \mathrm{C}$, in spite of the differences for the individual values, is the same for the whole country. The differences in the outside temperature above $20^{\circ} \mathrm{C}$ can be observed clearly. In Wroclaw there is $12 \%$ of such hours more, compared with the national average. This commeasures with the data presented in the literature [3] where the southwest region of Poland, especially the Odra River Valley, is presented as the warmest in the country, with the average annual temperature of the outside air exceeding $8^{\circ} \mathrm{C}$.

* Corresponding author: maria.kostka@pwr.edu.pl 


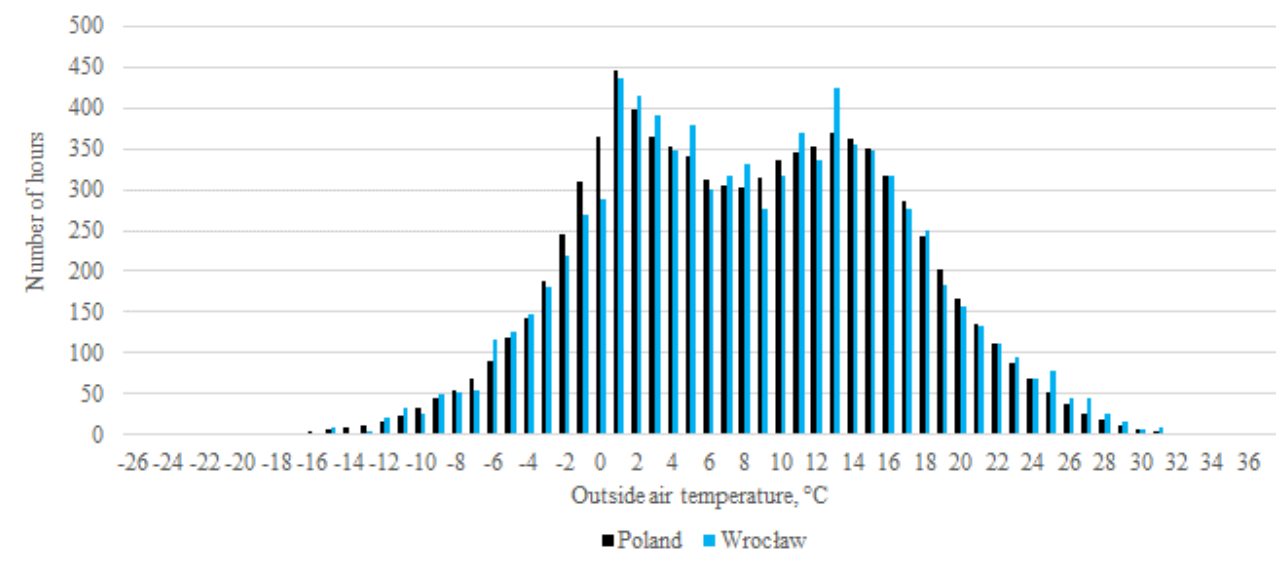

Fig. 1. The duration of the outside air temperature.

The percentage of outside air temperature ranges during the year for Poland and Wroclaw is shown in Figure 2. According to the drawing, for approximately $40 \%$ time of the year the temperature ranges between $1{ }^{\circ} \mathrm{C}$ and $10^{\circ} \mathrm{C}$. Clearly the dominant range is also $11^{\circ} \mathrm{C}-20^{\circ} \mathrm{C}$, which is almost $35 \%$.

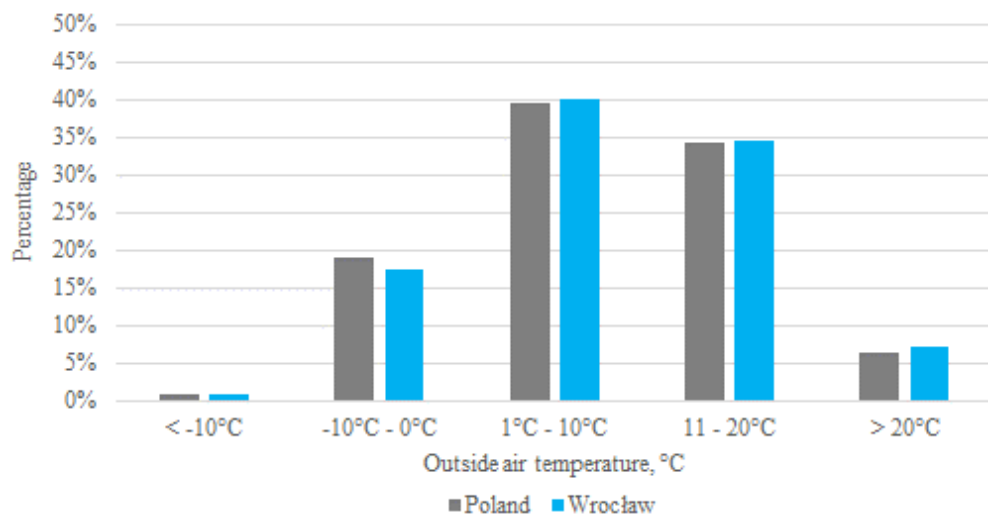

Fig. 2. The percentage of outside air temperature ranges during the year.

In Figure 3, the Mollier diagram describes the parameters of the outside air in Wrocław. The chart was developed on the basis of the Ministry data [2]. The highest outside air relative humidity in Poland is observed in winter - in January it ranges from 80 to $85 \%$, and the lowest in summer - in June, about $55-60 \%$ [3]. According to the Ministry, the average value of relative humidity in January in Wrocław is approximately $85 \%$ and does not diverge from the value of the country median. In summer the relative humidity is much higher than the average for the entire country: June and July $74 \%$, August $72 \%$. One of the reasons of it is the presence of rivers and watercourses such as Odra, Bystrzyca, Ślęza, Widawa, Dobra and Zielona.

The winds from the west are prevalent in Poland (30 - 35\%). South winds occurs during $20-25 \%$ of the year, and the east and north ones $15-20 \%$ [3]. East winds dominate in Wrocław only in March. In other months the west winds are prevalent [1]. The national average wind speed is $3-4 \mathrm{~m} / \mathrm{s}$ [3] and coincides with the average for Wrocław, which is approximately $3 \mathrm{~m} / \mathrm{s}[2]$. 


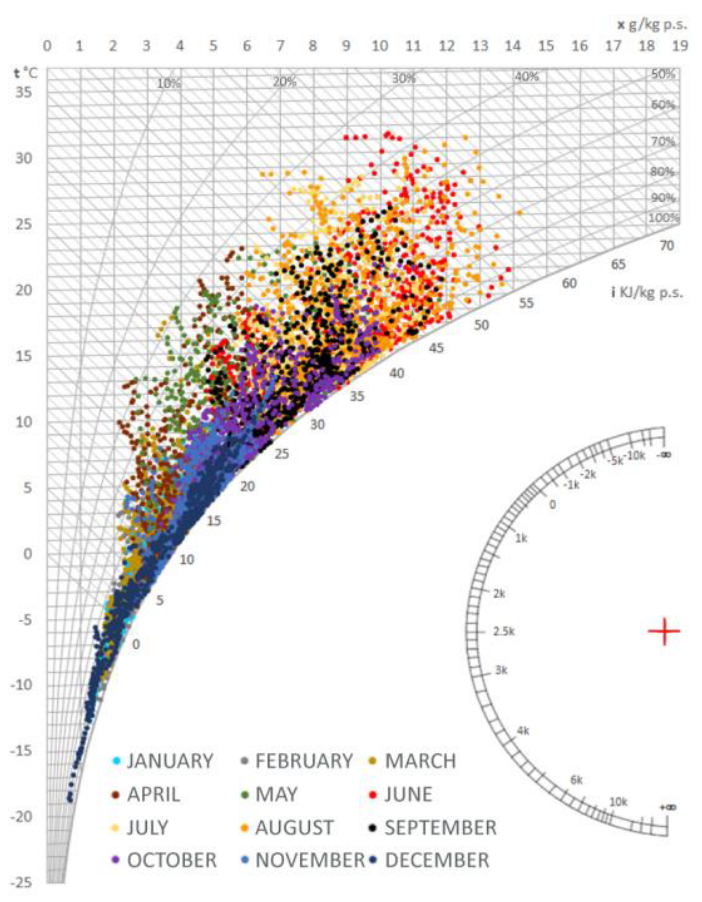

Fig. 3. The parameters of outside air - Wrocław.

\section{Residential ventilation}

The function of the ventilation in detached buildings is to ensure indoor air quality by removing the contaminants which appeared during regular exploitation of the building (e.g. laundry, cooking, metabolic contaminants) and replace it with fresh air. A typical ventilation in detached buildings in Poland is implemented in one of two ways - natural/gravity or mechanical. In the natural system the driving force of the air exchange is the pressure difference on the building partition, caused by the difference of internal and external temperature and wind. This is the basic system used over many years in the Polish construction industry. Along with the change of regulations related to the quality of buildings, their thermal insulation improvement and energy demand reduction the currently used mechanical systems are becoming popular. This type of ventilation in detached buildings reduces energy consumption, needed in the natural system for heating fresh air which is entering directly from the outside. Air exchange is provided by two fans placed in the air handling unit (AHU), equipped also with an exhaust air heat recovery exchanger, air filters and a heater. Typical heat recovery exchangers in the mechanical devices used in Poland are counterflow, cross-counterflow and rotary heat exchangers. Using of the heat recovery is crucial and justify the use of mechanical systems. In case of gravity ventilation used in low-energy building, financial expenses on outdoor air heating become a significant operating expense [4]. Mechanical ventilation allows reducing the cost of ventilation and ensures the constant air exchange efficiency, which is not possible in the case of natural ventilation in the Polish climate.

In detached buildings all sorts of natural systems assisted mechanically can be observed. They are called hybrid systems. P. Wouters, N. Heijmans, C. Delmotte and L. Vandaele [5] defined hybrid ventilation as a system that provides a comfortable internal environment using both, natural and mechanical systems at different times of the day and/or season of 
the year. Another solution can be mixed-mode ventilation (MMV) described by the University of California. It is designed and performed for exchanging the air in 3 ways: concurrent mixed-mode operation, change-over design and zoned system [6]. In concurrent mixed-mode operation mechanical device and operable windows operate in the same space and at the same time. In change-over design the building "changes-over" between natural ventilation and air conditioning unit on a seasonal or even daily basis. If we realized different ventilation strategies in different parts of building we can called this strategy zoned system.

\section{Literature review}

The mixed-mode ventilation is a relativity new subject area so there is no complete guide how to design and simulate such buildings [7]. There is also no direct literature sources evaluating the possibility of the use of this type of systems in the residential ventilation. But in the international professional press there are results of research on hybrid ventilation of this kind of buildings. The studies on the ventilation systems in residential construction, the natural ventilation potential and indoor air quality are currently conducting all over the world.

The assessment of the potential of the natural ventilation was made: for warm condition and temperate countries - I. Oropeza-Perez and P.A. Østergaad [8, 9], for warm and humid conditions - M. Haase, A. Amato [10], for United States - K. Hiyama, L. Glicksman [11] and Z. Cheng, L. Li, W.P. Bahnfleth [12]. Due to the lack of a comprehensive assessment of the possibilities for Poland, the closest example tests for a country with a temperate climate are the studies conducted by Ivan Oropeza-Perez and Poul Alberg Østergaad for Danmark house [9]. They showed that it is possible to maintain thermal comfort using the passive cooling with the $90 \%$ reduction of hours of the mechanical ventilation use. Because of the milder climate of Denmark we can expect smaller reductions in the use of mechanical ventilation in Poland.

The influence of window opening ventilation control on energy consumption and thermal comfort in residential building, naturally ventilated, located in Brazil presented by M.J. Sorgato, A.P. Melo and R. Lamberts [13]. They showed a significant impact of the residents' behavior on the thermal parameters of buildings. Research on optimization of opening dimensions for naturally ventilated buildings presented by L. Stephan, A. Bastide and E. Wurtz [14].

Studies of hybrid ventilation system for residential building with natural supply inlets and mechanical exhaust performed M. Kim and J. Hwang [15]. For an apartment located in Seoul they attempted to determine the airflow which provides comfortable thermal conditions and good air quality, also taking into account energy savings. Also hybrid systems studies described D. Jreijiry, A. Husaunndee and C. Inrad [16]. They compared two systems - mechanical extract and hybrid low-pressure in family building located in different locations (Greece, France and Sweden). The research showed that hybrid ventilation enables a decrease of more than $50 \%$ of the exposure of the occupants to high concentrations of $\mathrm{CO}_{2}$ while reducing at the same time the electrical energy consumed by the fan by $90 \%$.

Research of mixed-mode ventilation with natural ventilation and air conditioning system for office buildings presented M. Luo, B. Cao., J. Damiens, B. Lin and Y. Zhu [17], S. Ezzeldin, S.J. Rees [18], M. P. Deuble, R. J. de Dear [19] and A. Honnekeri, G. Brager, S. Dhaka and J. Mathur [20]. The authors focused on the building users thermal comfort and showed differences in their perception during the operation of natural and mechanical systems. Ezzeldin and Reeds also demonstrated the energy savings of mixed-mode ventilation. 
The studies conducted all over the world showed that combination of natural and mechanical ventilation systems can reduce energy consumption and provide thermal comfort. However, none of the research shows the case of Poland. Due to the differences between the countries, including e.g. climatic conditions or typical building structures, the results of the research should not be directly transferred to Poland. For this reason, there is a need to assess the potential of the hybrid systems operating in the Polish conditions.

\section{Ventilation system control strategy}

Considering the ventilation systems, the parameters of outside air in winter cause that it is reasonable to use mechanical ventilation equipped with heat recovery from exhaust air. This saves the energy needed for building heating. Also during summer, in the case of high outside temperature and days of windless weather, the use of fans and heat recovery system is justified because it maintains a proper air exchange in the building and reduces overheating of the interiors. The time of spring, autumn, summer evenings and nights are often characterized by parameters of air, which allow ventilation of buildings in a natural way. As a result, the consumption of electricity is reduced.

The use of mechanical ventilation system with heat recovery is economically justified when energy recovery from exhaust air enable reducing the costs associated with the building utilization. This situation in single-family buildings in Poland concerns mainly the heating season. It generally means that this ventilation would be cost-effective as long as the supply air temperature after heat recovery exchanger is higher than the outside air temperature, which would be delivered to the building in the case of natural ventilation. In fact this situation is not obvious and requires analyzing the costs of obtaining energy from mechanical ventilation (fans work, heat exchanger freeze protection) and the cost of producing energy in the heat source used in the building. Also heat gains and the phenomenon of the interiors overheating during the summer should be considered.

The aim of the research is to elaborate the energy-efficient ventilation control algorithm for detached houses, allowing to minimize the heating and ventilation costs, maintain comfortable indoor conditions and air quality. The analysis includes the type of heat source, the efficiency of the heating system, the type and efficiency of the heat recovery exchanger and the object location in Poland. Algorithms for manual and fully automatic switching strategy will be considered. Figure 4-5 shows examples of ventilation control algorithms with unknowns marked, which will be defined on the basis of the carried out analysis.
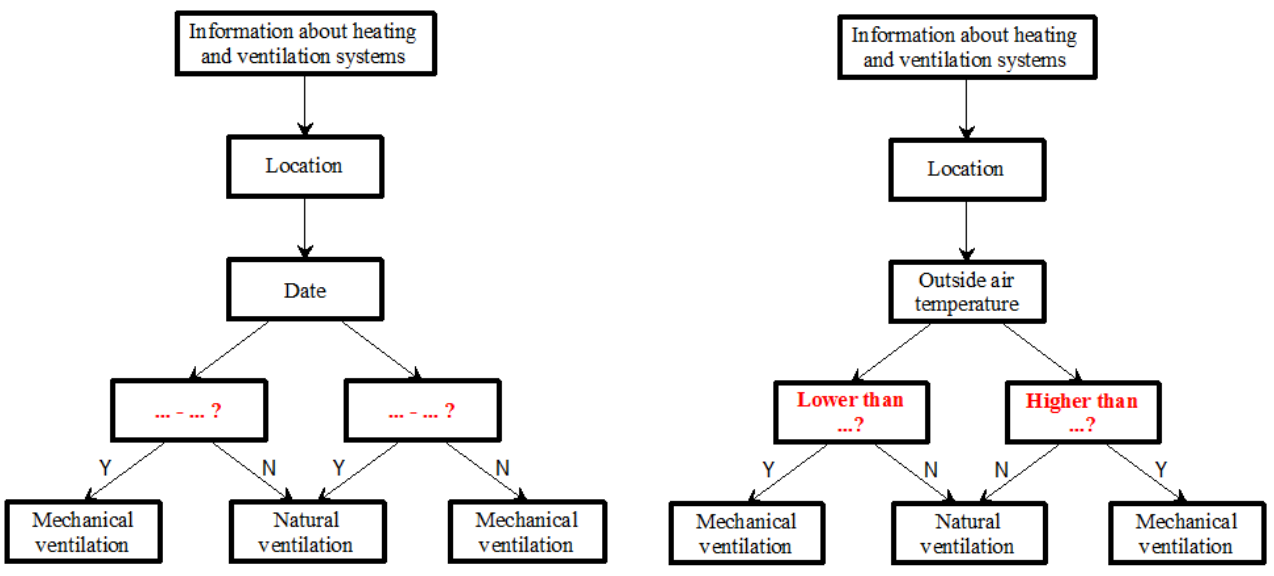

Fig. 4. Control algorithm for seasonal strategy (left) and outside air temperature strategy (right). 


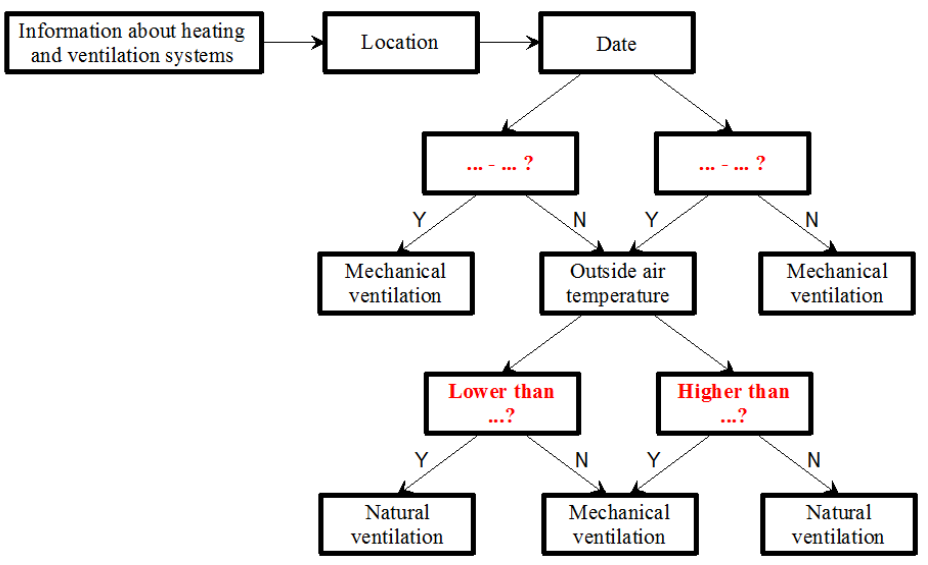

Fig. 5. Control algorithm for seasonal and outside air temperature strategy.

\section{Proposal of the research in situ}

For the proposed control strategies research on the existing detached house will be carried out. The hybrid change-over ventilation system was designed for building located near Wrocław.

a)

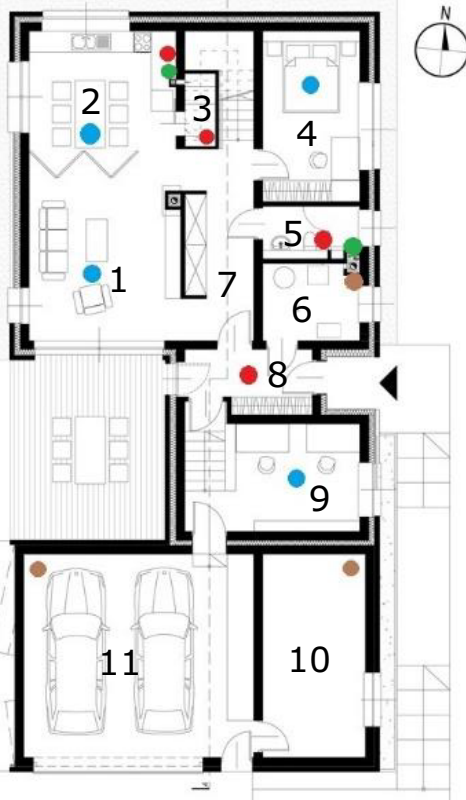

b)
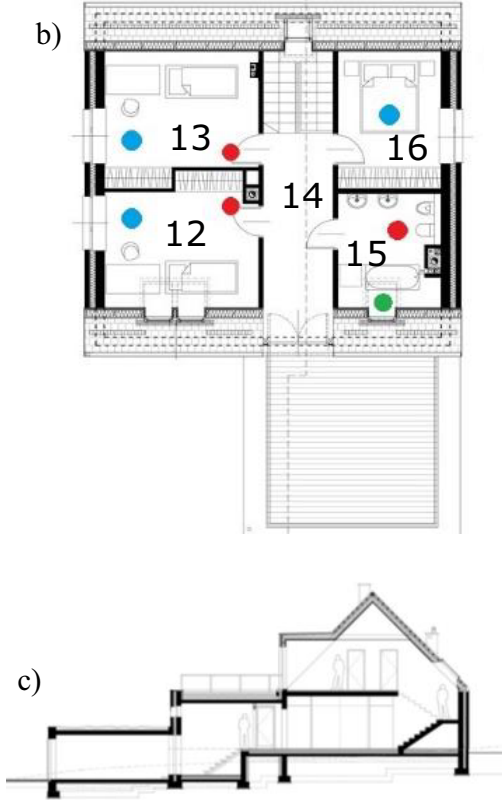

Fig. 6. Research object - detached house located near Wrocław: a) ground floor, b) attic, c) crosssection [21].
mechanical
ventilation
mechanical
ventilation
temporary natural ventilation
exhaust
constant natural exhaust
ventilation exhaust

1 -living room, 2 - kitchen, 3 - pantry, 4 - guest room, 5 - bathroom, 6 - technical room,

7 - corridor, 8 - vestibul, 9 - study room, 10 - utility room (unheated), 11 - garage (unheated),

12 - bedroom, 13 - bedroom, 14 - corridor, 15 - bathroom, 16 - bedroom. 
The building area is $190 \mathrm{~m}^{2}, 136 \mathrm{~m}^{2}$ of which is heated living space. It was built on a small hill and divided into 3 sections located at different heights (Figure 6c). The lowest part is the gravity ventilated garage and utility room, thermally isolated and separated by the airtight door. Above there is a study room, and the highest part is a two-storey living area. For those two parts the mechanical system and natural system was assumed and covered by the internal comfort and energy consumption research. The calculated heat demand of the building is $7.0 \mathrm{~kW}\left(51.5 \mathrm{~W} / \mathrm{m}^{2}\right.$ for heated zone). The heat source for the building is an air-water heat pump.

Mechanical supply and exhaust air volume is $350 \mathrm{~m}^{3} / \mathrm{h}$ and AHU is equipped with $85 \%$ efficiency rotary heat exchanger. In addition to the mechanical ventilation system for the ground floor rooms - the kitchen, the bathroom and the technical room (Figure 6a) the convective channels were constructed. The last of these rooms will be ventilated only in the natural way. For the rest of the rooms the separation of the systems are the spring return dampers. For the mechanical supply and exhaust installation the dampers closing by turning off the AHU were applied. The natural exhaust air from the bathroom in the attic (Figure 6b) will be provided through the opening of the roof window. The flow of air into the building during the action of natural ventilation is provided by manual unsealing/opening windows.

The real object research will consist of the measurements of indoor air parameters and parameters of air in the mechanical ventilation system (temperature, relative humidity, concentration of $\mathrm{CO}_{2}$, VOC). The heating and ventilation systems energy consumption data will also be analysed.

\section{Expected results}

The scheduled research will allow to identify the areas of Poland and the hybrid ventilation systems control strategies with the best economic effects. The research on the real object will verify the effectiveness of the ventilation systems and will be a data source about the indoor air quality and the thermal comfort in the naturally and mechanically ventilated residential buildings.

Depending on the hybrid system control strategy, the expected reduction of energy demand for the ventilation is from about $15 \%$ to over $50 \%$. It is necessary to include the energy consumption of all systems that provide thermal comfort in the building, so that the impact of hybrid ventilation on the final energy needed during the whole year will be assessed. The results of the final energy demand reduction depend mainly on the building energy standard, the climatic zone of Poland, the type of heat source and the ventilation system configuration. Expected reduction in final energy consumption for the purpose of ventilation and heating of buildings that meet current regulations in Poland is $10 \%-20 \%$. It should be noted that it is planned to strengthen regulations in the coming years. That will achieve better results, even exceeding $30 \%$. For the building described above, the use of natural ventilation for example during the outdoor temperature of $15^{\circ} \mathrm{C}-25^{\circ} \mathrm{C}$ will reduce the energy consumption for ventilation by about $25 \%$. Seasonal use for example from May to the end of September will increase it to about $40 \%$. The estimated reduction of final energy consumption for heating and ventilation of this building is approximately $20 \%$.

\section{Conclusions}

Single-family buildings represent a large share of the residential market in Poland and they are impacting significantly the energy consumption. For this reason, it is necessary to explore solutions that will lead to a reduction of energy needs in this sector. The results of 
the world research and the initial analysis of the parameters of the outside air in Poland indicate the possibility of reduction of the energy consumption in buildings by using hybrid ventilation systems that combine mechanical and natural installations.

This paper presents the proposal of the research that will lead to the creation of hybrid ventilation strategies for Poland. With the calculation analysis and simulations, the potential of this systems to energy consumption reduction will be assessed. The research in the existing building will evaluate the indoor air quality, thermal comfort and efficiency of natural, mechanical and hybrid systems.

This work is supported by funds from the Ministry of Higher Education for research and development works of young scientists and doctoral students. Project number: 0402/0098/16.

\section{References}

1. A. Woś, Struktura sezonowa klimatu Polski (Bogucki Wydawnictwo Naukowe, Poznań, 1996)

2. http://mib.gov.pl/2-Wskazniki_emisji_wartosci_opalowe paliwa.htm\# [access: 26.01.2017]

3. U. Kossowska - Cezak, D. Martyn, K. Olszewski, M. Kopacz - Lembowicz, Meteorologia i klimatologia, Pomiary, obserwacje, opracowania (PWN, Warszawa, 2010)

4. M. Kostka, M. Szulgowska - Zgrzywa, Rynek Instalacyjny 3 (2016)

5. P. Wouters, N. Heijmans, C. Delmotte, L. Vandeale, Classisication of hybrid ventilation cencepts, The Second International Forum of Natural and Hybrid Ventilation, HybVent Forum 99, Sydney, Australia 1999

6. http://www.cbe.berkeley.edu/mixedmode/aboutmm.html [access: 27.01.2017]

7. J.C. Salcido, A.A. Raheem, R.R.A. Issa, Energ. Buildings 127, 1008-1018 (2016)

8. I. Oropeza - Perez, P.A. Østergaard, Appl. Energ. 130, 20-32 (2014)

9. I. Oropeza - Perez, P.A. Østergaard, Appl. Energ. 14, 520-530 (2014)

10. M. Haase, A. Amato, Sol. Energy 83, 389-399 (2009)

11. K. Hiyama, L. Glicksman, Energy 89, 655-666 (2015)

12. Z. Cheng, L. Li, W.P. Bahnfleth, Build. Environ. 108, 85-98 (2016)

13. M.J. Sorgato, A.P. Melo, R. Lamberts, Energ. Buildings, 133, 1-13 (2016)

14. L. Stephan, A. Baside, E. Wurtz, Appl. Energ. 88, 2791-2801 (2011)

15. M. Kim, J. Hwang, Energ. Buildings, 41, 579-586 (2009)

16. D. Jreijiry, A. Husaunndee, C. Inard, Sol. Energy 81, 227-239 (2007)

17. M. Luo, B. Cao, J. Damiens, B. Lin, Y. Zhu, Build. Environ. 88, 46-54 (2015)

18. S. Ezzeldin, S.J. Rees, Energ. Buildings 65, 368-381 (2013)

19. M.P. Deuble, R.J. Dear, Build. Environ. 54, 53-60 (2012)

20. A. Honnekeri, G. Brager, S. Dhaka, J. Mathur, Comfort and adaptation in mixedmode buildings in a hot-dry climate, 8th Windsor Conference: Counting the Cost of Comfort in a Changing World 2014

21. http://apeagroup.pl/ [access: 26.01.2017] 